\title{
Blood pressure-independent effects of enhanced NO/cGMP signalling and gender on aortic remodelling in experimental renal hypertension
}

\author{
Bianca Grosz, Stephanie Krämer, Tanja Loof, Hans H Neumayer, \\ Yingrui Wang-Rosenke and Harm Peters*
}

Address: Department of Nephrology and Center for Cardiovascular Research, Charité-Universitätsmedizin, Berlin, Germany

Email: Harm Peters* - harm.peters@charite.de

* Corresponding author

from 4th International Conference of cGMP Generators, Effectors and Therapeutic Implications

Regensburg, Germany. 19-21 June 2009

Published: II August 2009

BMC Pharmacology 2009, 9(SuppI I):PI9 doi:I0.II86/I47I-22I0-9-SI-PI9

This abstract is available from: http://www.biomedcentral.com/I47I-22I0/9/SI/PI9

(c) 2009 Grosz et al; licensee BioMed Central Ltd.

\section{Background}

The most important comorbidity in renal patients is represented by cardiovascular complications, with impaired NO production as key pathway. In premenopause, estrogens seem to exert protective effects on the vascular system. This study investigates the effects of both gender and enhanced NO/cGMP signalling on aortic remodelling in experimental hypertensive nephropathy.

\section{Methods}

Age-matched male (M) and female (F) Wistar rats were assigned for 18 weeks into the following groups: 1) subtotally nephrectomized (SNX); 2) SNX Bay 41-8543-treated; 3) SNX hydralazine-treated and 4) sham operated. Bay 41-8543 is a NO-independent stimulator of soluble guanylate cyclase.

\section{Results}

SNX led to increases in systolic blood pressure, with lower levels in F rats (F-SNX $129 \pm 13 \mathrm{mmHg}$ vs. M-SNX $140 \pm$ $11 \mathrm{mmHg}$ ). Bay 41-8543 and hydralazine reduced blood pressure to control levels. Aortic remodelling was characterized by marked media thickening in both SNX groups, with a more pronounced increase in $M$ versus $F(127 \pm 9$ vs. $108 \pm 6 \%$ of control; $p<0.001)$. Intima-media ratio was reduced in both uremic groups, with significant sex differences (M-SNX $66 \pm 7 \%$ vs. F-SNX $80 \pm 8 \%$ of control; $\mathrm{p}<0.01)$. Furthermore, gender differences were observed in media-to-lumen ratio as indicator of aortic hypertrophy. The ratio was significantly higher in SNX males only (M-SNX $131 \pm 9 \%$ vs. F-SNX $107 \pm 15 \%$ of control; p < 0.001). Bay 41-8543 significantly ameliorated media thickness ( $111 \pm 10$ vs. $127 \pm 9 \%$ of control in $\mathrm{M} ; 101 \pm 7$ vs. $108 \pm 6 \%$ of control in F; p < 0.05), intima-media ratio ( $85 \pm 10$ vs. $66 \pm 7 \%$ of control in M; $91 \pm 6$ vs. $80 \pm 8 \%$ of control in $\mathrm{F}, \mathrm{p}<0.01)$ and media-to-lumen ratio (107 \pm 9 vs. $131 \pm 9 \%$ of control in $M ; p<0.001)$. Despite a similar reduction in blood pressure, hydralazine treatment did not alter aortic wall remodelling. These morphological changes were accompanied by elevated collagen I and reduced elastin protein expression at the level of aortic media, with decreased elastin/collagen ratio in untreated SNX groups, as marker of aortic wall stiffening. Bay 41-8543 treatment successfully prevented these molecular alterations (collagen I protein expression: $9.4 \pm$ 0.3 vs. $14.5 \pm 1.1 \%$ in females and $9.6 \pm 0.4$ vs. $16.1 \pm$ $1.0 \%$ in males), while hydralazine showed no effects. SNX was characterized by increased extracellular matrix turnover with up-regulation of MMP2 and TIMP1 genes, more pronounced in males than in females (M-SNX $1.8 \pm 0.1 \mathrm{vs}$. F-SNX $1.1 \pm 0.1$ for MMP2; M-SNX $4.2 \pm 0.8$ vs. F-SNX 2.7 \pm 0.6 for TIMP1; both expressed as relative values vs. controls). In the male Bay 41-8543-treated group, expression of these genes was significantly lower $(1.4 \pm 0.1 \mathrm{MMP} 2-$ 
relative expression and $1.8 \pm 0.4$ TIMP1-relative expression, $\mathrm{p}<0.05$ ).

\section{Conclusion}

The present study shows that in a model with hypertension and impaired renal function 1) aortic hypertrophy and remodelling is significantly more severe in male gender and 2) enhancing NO/GMP signalling by Bay 41-8543 ameliorates aortic wall changes significantly and in a blood pressure-independent manner.

Publish with Bio Med Central and every scientist can read your work free of charge

"BioMed Central will be the most significant development for disseminating the results of biomedical research in our lifetime. " Sir Paul Nurse, Cancer Research UK

Your research papers will be:

- available free of charge to the entire biomedical community

- peer reviewed and published immediately upon acceptance

- cited in PubMed and archived on PubMed Central

- yours - you keep the copyright 